\title{
OPEN Author Correction: Demonstration of facilitation between microalgae to face environmental stress
}

\author{
Emna Krichen, Alain Rapaport, Emilie Le Floc'h \& Eric Fouilland \\ Correction to: Scientific Reports https://doi.org/10.1038/s41598-019-52450-9, published online 05 November \\ 2019
}

The original version of this Article omitted an affiliation for Emna Krichen. The correct affiliations for Emna Krichen are listed below:

\author{
MARBEC, Univ. Montpellier, CNRS, IFREMER, IRD, Sète, France \\ MISTEA, Univ. Montpellier, INRA, SupAgro, Montpellier, France
}

ADEME, Agence de l'environnement et de la Maîtrise de l'Energie, 20 avenue du Grésillé, BP 90406, 49004 Angers Cedex 01, France

Additionally, the Acknowledgements section contained typographical errors and was incomplete.

"We thank Elodie Lanouguère for microalgae isolation and cultivation, Ariane Atteia for identifying the microalgal strains, Martine Fortune for ammonia analyses, Patrick Raimbault for carbon content analyses, and Christine Felix for giving helping hand to experiments monitoring. We would also like to thank Bènèdicte Fontez for assistance with statistical analyses, and Jèrome Harmand for fruitful comments and discussions during the MODEMIC research school on resource-consumer models (21-25 September 2015). This work was supported by the ADEME French Agency and the LabEx NUMEV incorporated into the I-Site MUSE funded by the French Research Agency (ANR) that have both funded the PhD grant of the first author. This study was also supported by the PHYCOVER project, which was funded by the French National Agency for Research (ANR-14-CE04-0011)."

now reads:

"We thank Elodie Lanouguère for microalgae isolation and cultivation, Ariane Atteia for identifying the microalgal strains, Martine Fortune for ammonia analyses, Patrick Raimbault for carbon content analyses, and Christine Felix for giving helping hand to experiments monitoring. We would also like to thank Bénédicte Fontez for assistance with statistical analyses, and Jérôme Harmand for fruitful comments and discussions during the MODEMIC research school on resource-consumer models (21-25 September 2015). This study benefited from the HRAP demonstrators developed and operated by SAUR. This work was supported by the ADEME French Agency and the LabEx NUMEV incorporated into the I-Site MUSE funded by the French Research Agency (ANR) that have both funded the PhD grant of the first author. This study was also supported by the PHYCOVER project, which was funded by the French National Agency for Research (ANR-14-CE04-0011)."

These errors have now been corrected in the PDF and HTML versions of the Article. 
(c) (i) Open Access This article is licensed under a Creative Commons Attribution 4.0 International License, which permits use, sharing, adaptation, distribution and reproduction in any medium or format, as long as you give appropriate credit to the original author(s) and the source, provide a link to the Creative Commons license, and indicate if changes were made. The images or other third party material in this article are included in the article's Creative Commons license, unless indicated otherwise in a credit line to the material. If material is not included in the article's Creative Commons license and your intended use is not permitted by statutory regulation or exceeds the permitted use, you will need to obtain permission directly from the copyright holder. To view a copy of this license, visit http://creativecommons.org/licenses/by/4.0/.

(C) The Author(s) 2020 